\title{
A Gender Based Case Control Study of Anthropometric and Renal Profile in Rural Diabetic Population
}

\author{
${ }^{1,}$ Mrs.Munilakshmi. U, ${ }^{2}$ Dr. Susanna T.Y, ${ }^{3}$ Dr. Shashidhar K.N, \\ ${ }^{4}$ Dr. Madhavi Reddy, ${ }^{5}$ Dr. Lakshmaiah. V, Ravishankar. $\mathrm{S}^{6}$ \\ 1,2,3,4,5,6, Sri Devaraj Urs Medical College Kolar
}

\begin{abstract}
OBJECTIVE: To evaluate the gender specific changes in anthropometric and renal parameters for the prediction of microvascular complications commonly diabetic nephropathy at its earlier stages through screening of diabetic patients.
\end{abstract}

MATERIALS AND METHODS: We studied total 150 subjects with Type 2 diabetes mellitus, duration of diabetes within 10 years, age group 50-60 years and equal number of age and gender matched clinically proven healthy controls during March 2011 to January 2012 were enrolled in our study. Anthropometric and biochemical parameters measurements were done by standard methods.

RESULTS: On comparison between non diabetics and diabetic subjects, waist circumference (WC), body mass index (BMI), waist hip ratio (WHR), obesity index, diastolic blood pressure (DBP), fasting blood sugar $(F B S)$, serum creatinine, spot urine albumin $(A E R)$ and albumin/creatinine ratio $(A C R)$ were significantly higher in diabetic males compared to non diabetic males and WC, BMI, DBP, FBS and SCr were significantly higher in diabetic females on comparison with non diabetic females. In Normoalbuminuric group (ACR $<30 \mathrm{mg} / \mathrm{g})$ WHR and AER was higher in males compared to females and in Microalbuminuric group (ACR 30$300 \mathrm{mg} / \mathrm{g}) W H R$, AER, FBS and ACR were significantly higher in males compared to females.

CONCLUSION: Significant increase in WHR was observed between male and female diabetics above the cutoff values as per the recommendations made by National Institute of Health Guidelines, and this study also confirmed that AER was higher in diabetic males compared to females which are clinical hallmarks for diabetic nephropathy and cardiovascular risk factors.

KEY WORDS: Albumin/creatinine ratio (ACR), albumin excretion rate (AER), body mass index (BMI), diabetic nephropathy, waist circumference (WC), waist hip ratio (WHR).

\section{INTRODUCTION}

Diabetes mellitus is a group of metabolic disease characterized by hyperglycemia resulting from defects in insulin secretion, insulin action or both ${ }^{[1]}$. The chronic hyperglycemia of diabetes leads to coronary artery and peripheral vascular disease, stroke and diabetic nephropathy resulting in reduced life expectancy and enormous health costs. Diabetes mellitus is recognized as a leading cause of chronic kidney disease and also end stage renal disease (ESRD) not only in developed countries but also in developing countries as a consequence of global increase in incidence of Type 2 diabetes mellitus and obesity ${ }^{[2]}$. Almost one third of T2DM patients eventually develop progressive deterioration of renal function leading to $\operatorname{ESRD}^{[3]}$. According to National Kidney Foundation Guidelines, patients with diabetes and microalbuminuria have twice the cardiovascular risk compared to normoalbuminuria. As albuminuria increases and GFR decreases, the CVD risk increases progressively and exponentially $y^{[4]}$. The two key markers to diagnose and monitor kidney damage in patients with T2DM are urine albumin/creatinine ratio (ACR) and eGFR ${ }^{[5]}$. However, creatinine excretion across the normal kidney is known to vary with age, gender, muscle mass, race and moreover ethnicity of a given population. Also anthropometric parameters like body mass index (BMI), Waist circumference (WC), Hip circumference (HC), Waist Hip Ratio (WHR) varies with gender among healthy population and were associated with increased risk of developing T2DM,complications of diabetes mellitus, hypertension and various cardiovascular diseases ${ }^{[6]}$. The purpose of this study is to assess the gender variations on anthropometric parameters and on various renal parameters including eGFR as calculated using a creatinine based equation developed from the Modification of Diet in Renal Disease (MDRD) study in our hospital which caters service to the rural population with type 2 diabetes mellitus. 
This in future may help the clinicians in early detection of complications commonly nephropathy through screening of diabetic patients, which will allow early intervention and better control of progression of microvascular and macrovascular complications, diabetic nephropathy and subsequent cardiovascular events and mortality among these patients can be minimized.

\section{METHODOLOGY}

Total 150 T2DM subjects with duration of diabetes within 10years and age group 50-60 years visiting RL Jalappa hospital and Research centre Kolar, Karnataka ,India, outpatient department during the year March 2011 to January 2012 and equal number of age and gender matched healthy controls were enrolled in our study. The study protocol was approved by the institutional ethical committee. Voluntary informed consent in their understandable language was obtained from all the study subjects. Male and female patients with Type 2 diabetes mellitus were made into 2 groups based on ACR cut offs as Normoalbuminuria $(<30 \mathrm{mg} / \mathrm{g})$ and Microalbuminuria $(30-300 \mathrm{mg} / \mathrm{g}$ ). Macroalbuminuria (males $=2$, females $=0$ ) indicating overt nephropathy were excluded from our study.

Group I comprised $\mathrm{n}=135$ normoalbuminuria (males $=94$, females $=41$ )

Group 2 comprised $n=13$ microalbuminuria (males $=9$, females $=4$ )

Exclusion criteria - patients with cardiovascular disease, hepatic /renal disease, type 1 diabetes mellitus, peripheral vascular disease, acute or chronic infection, cancer, which might affect the various biochemical parameters estimated, were excluded from the study. Clinical details of the patients were obtained from the hospital medical records. All subjects enrolled in the study underwent detailed clinical examination including measurements of height, weight, WC, HC, systolic and diastolic blood pressure. Fasting venous blood was drawn from all patients under aseptic precautions as per requirement and processed accordingly for the assay of Fasting blood glucose (FBS), serum creatinine (SCr) and serum uric acid sample centrifuged at $3000 \mathrm{rpm}$ for 10 minutes and supernatant was separated for analyses. For spot urine albumin (AER), urine creatinine, a random urine sample was collected and all the parameters were estimated using Johnson and Johnson vitros 250 dry chemistry auto analyzer. The blood glucose estimation was done by Glucose Oxidase Peroxidase method (GODPOD) ${ }^{[7]}$, serum creatinine was estimated by Jaffes method ${ }^{[8]}$, uric acid estimation by uricase method ${ }^{[8]}$ and eGFR was calculated ${ }^{[9]}$. Estimation of urine creatinine and urine albumin was done by Jaffes method and dip stick analysis respectively ${ }^{[8]}$.The study group was divided into 2 groups based on Albumin/Creatinine ratio (ACR) as Normoalbuminuric ( $\leq 30 \mathrm{mg} / \mathrm{g}$ ) and Microalbuminuric $(30-300 \mathrm{mg} / \mathrm{g})$.

\section{STATISTICAL ANALYSIS}

The values of Anthropometric and Biochemical parameters are expressed as mean with standard deviation. We compared all clinical variables among males and females with T2DM with males and females without diabetes respectively and also compared these variables between males and females with T2DM in Group I and between males and females with T2DM in Group II. Significance of the difference between male and female diabetics was evaluated by Student-t test using SPSS version 16.0 and the p value $<0.05$ was considered as significant.

\section{RESULTS}

The present study observed significantly altered values with respect to anthropometric and biochemical parameters in diabetic males and females when compared with healthy controls (table: 1).With respect to anthropometric parameters the WC, BMI and obesity index were significantly higher in diabetic males as compared to non diabetic males and also consequently the diastolic blood pressure was also elevated among male diabetics and with respect to biochemical parameters FBS, SCr, AER and ACR were significantly higher among diabetic males as compared to non diabetic males. When the anthropometric parameters among female diabetics was observed there was significant increase in WC and BMI and increase in diastolic blood pressure (DBP) compared to non diabetic females. With respect to biochemical parameters only FBS and SCr were statistically significant compared to non diabetic females.

All the variables were also compared between females and males of normoalbuminuria and microalbuminuria groups (table: 2).

Group I: Normoalbuminuria ( $\mathrm{n}=135$; males $=94$, females $=41)$ with $\mathrm{ACR} \leq 30 \mathrm{mg} / \mathrm{g}$

In the Normoalbuminuric group the mean age (57.75years), WC $(96.12 \mathrm{~cm}), \mathrm{HC}(95.31 \mathrm{~cm})$, WHR $(0.94)$, BMI $\left(24.53 \mathrm{~kg} / \mathrm{m}^{2}\right)$, obesity index $(66.23 \mathrm{~cm})$, SBP $(128 \mathrm{mmHg})$, DBP $(82 \mathrm{mmHg})$ FBS $(139.77 \mathrm{mg} / \mathrm{dl}), \quad$ SCr $(1.05 \mathrm{mg} / \mathrm{dl}), \mathrm{HbA} 1 \mathrm{c}(9.78 \%)$, uric acid $(5.36 \mathrm{mg} / \mathrm{dl})$, AER $(462.61 \mathrm{mg} / \mathrm{dl})$, spot urine creatinine $(87.55)$, ACR $(66.13 \mathrm{mg} / \mathrm{g})$ and eGFR $\left(66.85 \mathrm{ml} / \mathrm{min} / 1.73 \mathrm{~m}^{2}\right)$ in male diabetes subjects and in female diabetic subjects are age (55.75years), WC $(92.51 \mathrm{~cm})$, HC $(97.48 \mathrm{~cm})$, WHR $(0.92)$, BMI $\left(26.23 \mathrm{~kg} / \mathrm{m}^{2}\right)$, obesity index $(54 \mathrm{~cm})$, SBP $(124 \mathrm{mmHg})$, DBP $(78 \mathrm{mmHg}), \mathrm{FBS}(152.17 \mathrm{mg} / \mathrm{dl}), \mathrm{SCr}(0.84 \mathrm{mg} / \mathrm{dl}), \mathrm{HbA} 1 \mathrm{c}(9.22 \%)$, uric acid $(4.28 \mathrm{mg} / \mathrm{dl})$, 
AER (279.44mg/dl), spot urine creatinine (88.06), ACR $(62.22 \mathrm{mg} / \mathrm{g})$ and eGFR $\left(55.60 \mathrm{ml} / \mathrm{min} / 1.73 \mathrm{~m}^{2}\right)$ was observed respectively. Among these variables WHR and AER was statistically significant in males. Group II: Microalbuminuria ( $n=13$; males $=9$, females $=4$ ) with ACR $30-300 \mathrm{mg} / \mathrm{g}$. In Microalbuminuric group the mean values for age $\left(52\right.$ years), WC $(94.77 \mathrm{~cm}), \mathrm{HC}(94.33 \mathrm{~cm})$, WHR $(1.00)$, BMI $\left(22.72 \mathrm{~kg} / \mathrm{m}^{2}\right)$, obesity index $(69.72 \mathrm{~cm}), \mathrm{SBP}(134 \mathrm{mmHg}), \mathrm{DBP}(84 \mathrm{mmHg}) \mathrm{FBS}(163 \mathrm{mg} / \mathrm{dl}), \mathrm{SCr}(1.87 \mathrm{mg} / \mathrm{dl}), \mathrm{HbA} 1 \mathrm{c}(10.07 \%)$, uric acid $(4.22 \mathrm{mg} / \mathrm{dl})$, AER $(2122.20 \mathrm{mg} / \mathrm{dl})$, spot urine creatinine $(87.00)$, ACR $(69.30 \mathrm{mg} / \mathrm{g})$ and eGFR $(59.66$ $\mathrm{ml} / \mathrm{min} / 1.73 \mathrm{~m} 2$ ) in male diabetes subjects and in diabetic females 46 years, $90 \mathrm{~cm}, 95.25 \mathrm{~cm}, 27.15 \mathrm{~kg} / \mathrm{m} 2,0.94$, $56.93 \mathrm{~cm}, 126 \mathrm{mmHg}, 80 \mathrm{mmHg}, 102 \mathrm{mg} / \mathrm{dl}, 0.93 \mathrm{mg} / \mathrm{dl}, 9.76 \%, 5.20 \mathrm{mg} / \mathrm{dl}, 575 \mathrm{mg} / \mathrm{dl}, 76.50,68.70 \mathrm{mg} / \mathrm{g}$, $50.25 \mathrm{ml} / \mathrm{min} / 1.73 \mathrm{~m}^{2}$ for age, WC, HC, BMI, WHR, obesity index, SBP, DBP, FBS, SCr, HbA1c, uric acid, AER, spot urine creatinine, ACR and eGFR respectively. Among these parameters WHR, FBS, AER and ACR were significant when compared between microalbuminuric males and females.

\section{DISCUSSION}

The present study has made an attempt to evaluate the influence of gender on various anthropometric and renal parameters among diabetic patients. As diabetic nephropathy is the single leading cause of ESRD, studies have found that diabetic nephropathy occurs in $20-40 \%$ of patients with diabetes (10). Persistent albuminuria in the range of $30-300 \mathrm{mg} /$ day is a marker for the development of nephropathy in T2DM, and the diabetic population with microalbuminuria is at increased risk of developing cardiovascular and renal disease ${ }^{[10]}$. Previous studies have reported that anthropometric indices like WC, BMI, and WHR raised with gender and was associated with prediction of cardiovascular risk factors, importantly the WC was found to be a better predictor among women as compared to men, where the WC and WHR which reflects central adiposity, among men was also associated with variation in blood pressure, plasma glucose, albuminuria and lipid levels. In women all these parameters i.e WC, WHR and BMI was found to be associated with variance in blood pressure, blood glucose and albuminuria. Similarly our study found significantly higher WC, BMI, blood pressure, FBS and SCr among both diabetic males and females compared to age and sex matched healthy controls ${ }^{[6,11]}$. Among the anthropometric parameters compared between the gender groups with diabetes we observed that the female diabetic patients had mean WC much higher $>88 \mathrm{cms}$ compared to BMI which was within cut off limits recommended by the National Institute of Health Guidelines as compared to WC of males which was within the recommended cutoff limits. This shows that although the WC and BMI are interrelated, WC would provide an independent predictor of risk for various metabolic complications over and above that of BMI.WHR also was found to be higher than the normal cut off range both among males and females. However, it was not statistically significant ${ }^{[4]}$.

Although FBS and HbA1C was found to be higher in males and females in both normoalbuminuric and microalbuminuric group only few patients with hyperglycemia and poor glycemic control developed microalbuminuria. Estimation of FBS and $\mathrm{HbA} 1 \mathrm{C}$ alone will not be sufficient to determine the risk of a diabetic patient developing microalbuminuria, hence the authors suggest estimation of ACR to be done in diabetic patients invariably during each follow up for early detection of microalbuminuria ${ }^{[12]}$. We also observed that the AER and ACR was found to be higher in males as compared to females, similar findings were observed by Cirillo $\mathrm{M}$ et al and Vestbo et al in the studies done on albumin excretion rate in timed urine samples, which showed that males excrete albumin at higher rate than females thereby making them prone for not only increased risk but also faster progression of diabetic nephropathy ${ }^{[12,13]}$. The higher rate of excretion of albumin in men compared to women can be attributed to the male gender itself, smoking habits as the component nicotine increases oxidative stress, by the secretion of superoxide due to activation of NADPH oxidase and protein kinase $\mathrm{C}$ (PKC) this can ultimately damage the kidney. In our study all male patients had a history of smoking for more than three years and the other cause can also be due to alteration in the renal endothelial function, the nitric oxide (NO) availability in renal circulation is greater in women than in men with T2DM that is associated with reduced oxidative stress and has an important role in the initiation and progression of Diabetic nephropathy ${ }^{[14,15]}$. However, similar to the findings made by Festa A etal and Gerstein HC etal., we also observed the percentage of female diabetic patients developing microalbuminuria was slightly higher when compared to male diabetic patients which may be attributed to lower urine creatinine concentration but not to urinary albumin excretion because creatinine which is a metabolic byproduct of skeletal muscle, creatine and phosphocreatine metabolism is lower in subjects with lower muscle mass such as women and elderly ${ }^{[16,17]}$.

From our own study it is evident that there are however a few important differences between anthropometric and renal parameters in diabetic men and women. These gender differences in clinical presentation in diabetics have greater implications in management strategies and planning for health care delivery in the community. 
However, future studies with larger population size and also including other microvascular complications in diabetic patients has to be taken into consideration to come to a concrete decision on the gender differences on anthropometric and renal parameters. The understanding of this difference may add to the understanding of the pathogenesis of diabetes complications in men and women with type 2 diabetes.

The study concludes that, significant increase in WHR was observed between male and female diabetics above the cutoff values as per the recommendations made by National Institute of Health Guidelines, and this study also confirmed that diabetic males excreted higher quantity of albumin compared to females which is an independent risk factor to determine the cardiovascular risk and progression of diabetic nephropathy.

\section{REFERENCES}

[1] Mahato RV, Gyawali P, Raut P, Regmi P,et al. Association between glycemic control and serum lipid profile in type 2 diabetic patients: Glycated hemoglobin as a dual biomarker .Biomedical Research 2011; 22 (3): 375-380

[2] AJKDKDOQI Clinical Practice Guidelines and Clinical Practice Recommendations for Diabetes and Chronic Kidney Disease. $2007 ;$ 49(2):[Supp12].

[3] Remizzi G, Clinical practice Nephropathy in patients with T2DM. New Engl J Med. 2002; 347:947-948.

[4] National kidney foundation guidelines AJKD. 2007:49(2):[Suppl 2].

[5] NKDEP National kidney foundation program NIH publication No.10-6286, 2010.

[6] Ho SC, Chan YM, Woo JLF et al. Association between simple anthropometric indices and cardiovascular risk factors.International journal of obesity.2001; 25:1689-1697.

[7] David B Sacks MB. Estimation of Blood Glucose. In: Teitz, BurtisCA, eds. Clinical chemistry and Molecular Diagnostics. 4thed.New Delhi: Elsevier, 1999, pp 870-871.

[8] Edmund Lamb, David J, Cristopher P. Creatinine estimation. In:Teitz, Burtis CA, eds. Clinical chemistry and MolecularDiagnostics. 4th ed. New Delhi: Elsevier, 1999, pp 798

[9] Levy AS, Bosch JP, Lewis JB, et al. A more accurate method toestimate glomerular filtration rate from serum creatinine: anew prediction equation. Modification of diet in renal diseasestudy group. Ann Intern Med 1990; 130:461-470.

[10] American Diabetes association standards of medical care and Diabetes 2013.

[11] Ko GT, Chen JC, Woo JLF. Simple anthropometric indices and cardiovascular risk factors in Chinese.Int J obes Relat Metab Disorders. 1997; 21(11):995-1001.

[12] Cirillo M, Senigallesi L, Laurenzi M, et al. microalbuminuria in non diabetic adults: relation of blood pressure, body mass index, plasma cholesterol levels, and smoking: the Gubbio population study. Arch Intern Med 1998; 158: 1933-1939.

[13] Vestbo E, Damsgaard EM, Froland A, et al. urinary albumin excretion in a population based cohort. Diabet Med 1995; 12 : $488-493$.

[14] Markus P, Martin R, Ulrike R, Christian O, Roland E. Gender is related to alterations of renal endothelial function in type 2 diabetes,Nephrol Dial Transplant 2009; 24: 3354-3359.

[15] Chakkarwar VA, Krishan P. Combinating NADPH Oxidase in Diabetic Nephropathy: Most logical therapeutic target. JAPHR 2011;1:39-45.

[16] Festa A, D, Agostino R, Howard G, Mykkanen L, Tracy RP, Haffner SM: inflammation and microalbuminuria in non diabetic and type 2 diabetic subjects: The insulin resistance Atherosclerosis study. Kidney Int 200;58: 1703-1710.

[17] Gerstein HC, Mann JFE, Pogue J, Dinneen SF, Halle JP et al for the HOPE study investigators: prevalence and determinants of microalbuminuria in high risk diabetic and non diabetic patients in the Heart Outcomes Prevention Evaluation study. Diabetes care 23 [Suppl 2]: B35-B39, 2000.

1. General comparison between non diabetes and diabetes

\begin{tabular}{|l|l|l|l|l|}
\hline Sl.no & Parameters & Gender & $\begin{array}{l}\text { Non diabetic controls } \\
\text { (males=87, females=64) }\end{array}$ & $\begin{array}{l}\text { Diabetic } \\
\text { (males=105, } \\
\text { females=44) }\end{array}$ \\
\hline 1 & Age & Males & $51 \pm 11.18$ & $56 \pm 11.34$ \\
\hline & & Females & $50 \pm 9.67$ & $55 \pm 10.55$ \\
\hline 2 & Waist circumference $(\mathrm{cm})$ & Males & $94.59 \pm 8.01^{*}$ & $95.72 \pm 11.52^{*}$ \\
\hline & & Females & $89.87 \pm 14.26^{*}$ & $92.28 \pm 13.60^{*}$ \\
\hline 3 & Hip circumference $(\mathrm{cm})$ & Males & $97.21 \pm 9.19$ & $95.11 \pm 10.30$ \\
\hline & & Females & $100.06 \pm 40.30$ & $97.28 \pm 12.25$ \\
\hline 4 & BMI $\left(\mathrm{kg} / \mathrm{m}^{2}\right)$ & Males & $28.63 \pm 33.73^{*}$ & $24.33 \pm 3.54^{*}$ \\
\hline & & Females & $24.63 \pm 5.53^{*}$ & $26.32 \pm 4.41^{*}$ \\
\hline 5 & WHR & Males & $0.97 \pm 0.09$ & $1.01 \pm 0.12$ \\
\hline & & Females & $0.93 \pm 0.18$ & $0.95 \pm 0.12$ \\
\hline 6 & Obesity $\mathrm{index}$ & Males & $64.83 \pm 14.47^{*}$ & $66.27 \pm 7.59^{*}$ \\
\hline & & Females & $51.32 \pm 10.47$ & $55.13 \pm 6.94$ \\
\hline 7 & SBP $(\mathrm{mmHg})$ & Males & $124 \pm 15.76$ & $128 \pm 14.50$ \\
\hline & & Females & $122 \pm 13.13$ & $124 \pm 12.63$ \\
\hline 8 & DBP $(\mathrm{mmHg})$ & Males & $82 \pm 9.13^{*}$ & $82 \pm 10.70^{*}$ \\
\hline & & Females & $80 \pm 8.84^{*}$ & $78 \pm 11.08^{*}$ \\
\hline 9 & FBS $(\mathrm{mg} / \mathrm{dl})$ & Males & $99.80 \pm 55.40^{*}$ & $143.53 \pm 71.61^{*}$ \\
\hline & & Females & $97.78 \pm 47.29^{*}$ & $147.71 \pm 65.75^{*}$ \\
\hline 10 & Scr $(\mathrm{mg} / \mathrm{dl})$ & Males & $0.92 \pm 0.22^{*}$ & $1.12 \pm 0.87^{*}$ \\
\hline & & Females & $0.65 \pm 0.13^{*}$ & $0.84 \pm 0.32^{*}$ \\
\hline 11 & Uric acid $(\mathrm{mg} / \mathrm{dl})$ & Males & $5.22 \pm 1.30$ & $5.26 \pm 5.40$ \\
\hline
\end{tabular}


A Gender Based Case Control Study Of Anthropometric...

\begin{tabular}{|l|l|l|l|l|}
\hline & & Females & $3.99 \pm 1.19$ & $4.36 \pm 1.00$ \\
\hline 12 & HbA1c (\%) & Males & $8.78 \pm 6.06$ & $11.07 \pm 7.08$ \\
\hline & & Females & $9.03 \pm 3.56$ & $10.05 \pm 3.63$ \\
\hline 13 & Spot urine albumin & Males & $174.57 \pm 238.17 *$ & $609.20 \pm 983.36^{*}$ \\
\hline & & Females & $208.83 \pm 287.37$ & $305.71 \pm 287.37$ \\
\hline 14 & Spot urine creatinine & Males & $89.96 \pm 115.19$ & $63.12 \pm 52.08$ \\
\hline & & Females & $86.78 \pm 150.92$ & $57.73 \pm 51.95$ \\
\hline 15 & ACR $(\mathrm{mg} / \mathrm{g})$ & Males & $2.91 \pm 4.50^{*}$ & $24.61 \pm 66.37^{*}$ \\
\hline & & Females & $6.93 \pm 33.88$ & $13.18 \pm 27.57$ \\
\hline
\end{tabular}

$* \mathrm{p}<0.05$ considered as significant

2. Comparison of anthropometric and renal parameters between male and female T2DM patients in Normoalbuminuric and Microalbuminuric groups 3

\begin{tabular}{|c|c|c|c|c|}
\hline Sl.no. & Parameters & Gender & 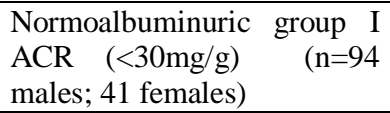 & $\begin{array}{l}\text { Microalbuminuric } \text { group } \\
\text { ACR (30-300mg/g) } \quad(n=9 \\
\text { males; } 4 \text { females) }\end{array}$ \\
\hline \multirow[t]{2}{*}{1} & Age & Males & $57.75 \pm 11.22$ & $52 \pm 7.68$ \\
\hline & & Females & $55.75 \pm 1.55$ & $46 \pm 13.47$ \\
\hline \multirow[t]{2}{*}{2} & Waist circumference $(\mathrm{cm})$ & Males & $96.12 \pm 11.25$ & $94.77 \pm 13.26$ \\
\hline & & Females & $92.51 \pm 13.26$ & $90.00 \pm 19.02$ \\
\hline \multirow[t]{2}{*}{3} & Hip circumference $(\mathrm{cm})$ & Males & $95.31 \pm 10.42$ & $94.33 \pm 8.71$ \\
\hline & & Females & $97.48 \pm 11.68$ & $95.25 \pm 19.34$ \\
\hline \multirow[t]{2}{*}{4} & BMI $\left(\mathrm{kg} / \mathrm{m}^{2}\right)$ & Males & $24.53 \pm 3.50$ & $22.72 \pm 3.89$ \\
\hline & & Females & $26.23 \pm 4.30$ & $27.15 \pm 6.08$ \\
\hline \multirow[t]{2}{*}{5} & WHR & Males & $0.96 \pm 0.09^{*}$ & $1.00 \pm 0.15$ \\
\hline & & Females & $0.92 \pm 0.10$ & $0.94 \pm 0.11^{*}$ \\
\hline \multirow[t]{2}{*}{6} & Obesity index & Males & $66.23 \pm 12.27$ & $67.02 \pm 14.36$ \\
\hline & & Females & $54.12 \pm 10.12$ & $56.93 \pm 12.32$ \\
\hline \multirow[t]{2}{*}{7} & SBP (mmHg) & Males & $128 \pm 12.54$ & $134 \pm 27.67$ \\
\hline & & Females & $124 \pm 12.96$ & $126 \pm 10.00$ \\
\hline \multirow[t]{2}{*}{8} & DBP $(\mathrm{mmHg})$ & Males & $81 \pm 9.84$ & $84 \pm 18.70$ \\
\hline & & Females & $78 \pm 11.40$ & $80 \pm 8.16$ \\
\hline \multirow[t]{2}{*}{9} & FBS (mg/dl) & Males & $139.77 \pm 63.24$ & $163.44 \pm 114.43^{*}$ \\
\hline & & Females & $152.17 \pm 67.11$ & $102.00 \pm 17.30$ \\
\hline \multirow[t]{2}{*}{10} & $\mathrm{SCr}(\mathrm{mg} / \mathrm{dl})$ & Males & $1.05 \pm 0.41$ & $1.87 \pm 2.69$ \\
\hline & & Females & $0.84 \pm 0.32$ & $0.93 \pm 0.44$ \\
\hline \multirow[t]{2}{*}{11} & HbA1c (\%) & Males & $9.78 \pm 7.16$ & $10.07 \pm 8.40$ \\
\hline & & Females & $9.22 \pm 2.48$ & $9.76 \pm 2.50$ \\
\hline \multirow[t]{2}{*}{12} & Uric acid (mg/dl) & Males & $5.36 \pm 5.72$ & $4.22 \pm 1.39$ \\
\hline & & Females & $4.28 \pm 0.95$ & $5.20 \pm 1.32$ \\
\hline \multirow[t]{2}{*}{13} & Spot urine albumin & Males & $462.61 \pm 647.48^{*}$ & $2122.20 \pm 2206.31 *$ \\
\hline & & Females & $279.44 \pm 271.92$ & $575.00 \pm 345.30$ \\
\hline \multirow[t]{2}{*}{14} & Spot urine creatinine & Males & $87.55 \pm 28.93$ & $87.00 \pm 32.78$ \\
\hline & & Females & $88.06 \pm 29.68$ & $76.50 \pm 23.75$ \\
\hline \multirow[t]{2}{*}{15} & $\mathrm{ACR}(\mathrm{mg} / \mathrm{g})$ & Males & $66.13 \pm 52.08$ & $69.30 \pm 48.09^{*}$ \\
\hline & & Females & $62.22 \pm 52.20$ & $68.70 \pm 12.25$ \\
\hline \multirow[t]{2}{*}{16} & eGFR & Males & $66.85 \pm 7.40$ & $59.66 \pm 6.68$ \\
\hline & & Females & $55.60 \pm 6.35$ & $50.25 \pm 11.52$ \\
\hline
\end{tabular}


Figure 1: showing the difference of waist hip ratio between diabetic males and diabetic females

\section{WAIST HIP RATIO}

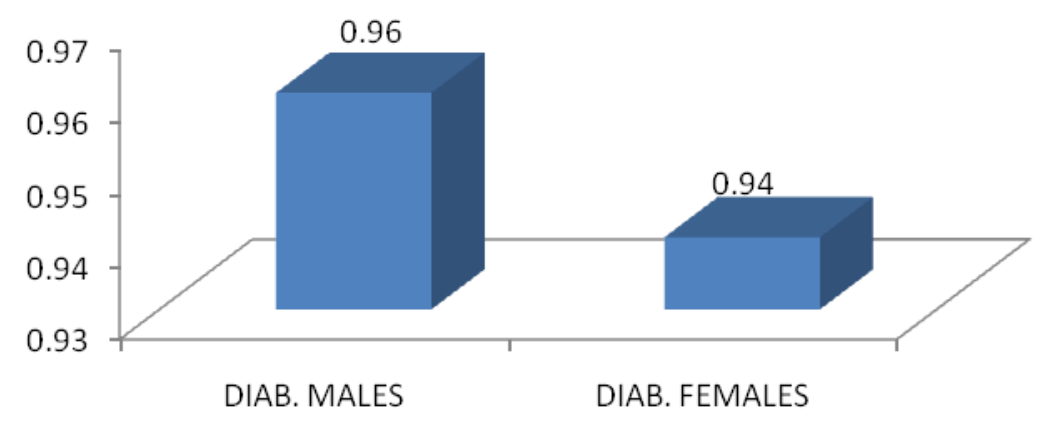

Figure 2: showing the comparison of AER in T2DM males and females

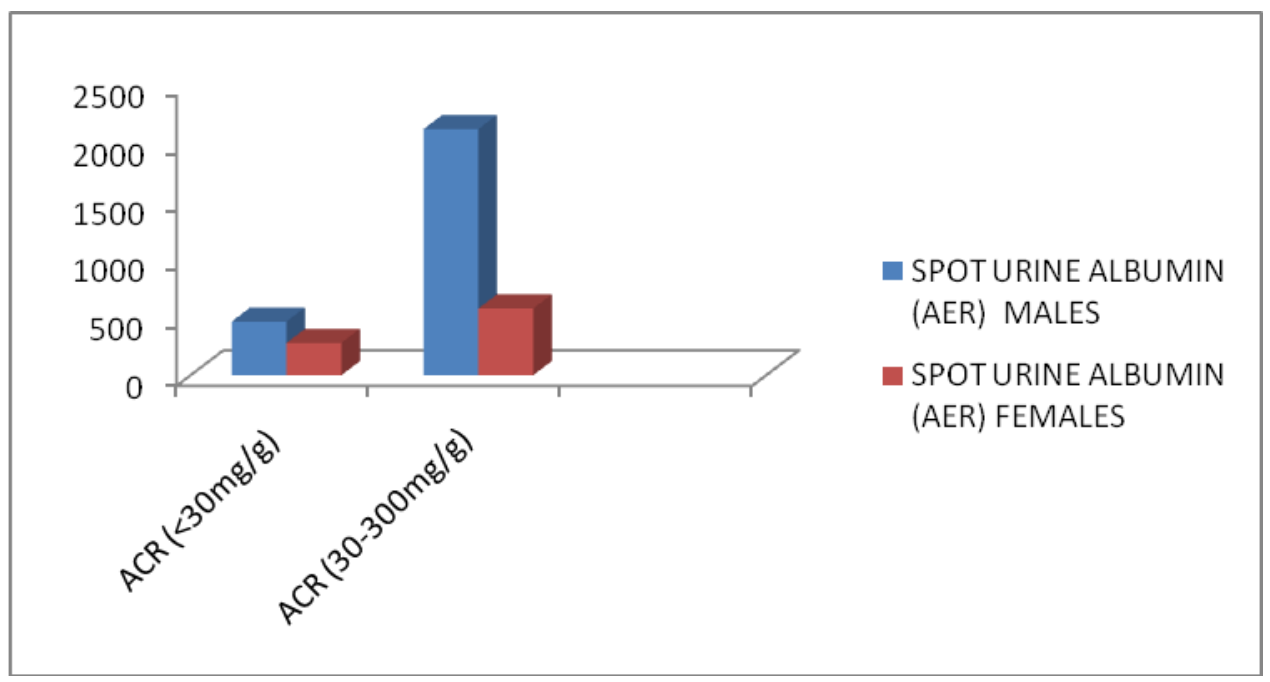

